\title{
THE ACTIVITIES OF BANK EXAMINERS WITH RESPECT TO TRUST INVESTMENTS ${ }^{2}$
}

\author{
E. P. NeILAN*
}

The extension of the scope of the work of bank examiners to include review of the investment policies and practices within the trust departments of banks is of comparatively recent date. Surveys indicate that examinations before 2933 consisted of little more than a physical check of the assets held in these departments. ${ }^{2}$ Prior to that time, trust functions quite generally were regarded by the majority of supervisory authorities as bailee duties, and few examiners were qualified to analyze the policies and practices utilized by the banks in the investment of trust funds. ${ }^{8}$ The limited nature of the examination appears to have been a direct result of these circumstances.

The isolated examples of trust maladministration which gained widespread public attention during the period from 1929 to $1933^{4}$ prompted a thorough revision of methods employed in trust examination work. Supervisors were faced with the fact that poorly conceived policies and weak administration in the trust department might be as detrimental to the solvency of the bank as unsound policies and weak administration in the banking department. After years of reliance on the general concept that state courts were charged with the sole responsibility for proper trust administration, banking authorities discovered that many courts were so burdened with litigation that they had neither the time nor the facilities to inquire thoroughly into the administration of each trust account presented to them for approval. These courts were powerless to compel an accounting in a number of jurisdictions unless it was requested by the petition of some interested party and generally had no authority over many trusts under agreement unless litigation was instituted. In all except a few jurisdictions, the courts could not approve or disapprove the trustee's course of

* B.A., I928, Rice Institute; Diploma of Graduation, 1937, Graduate School of Banking, Amcrican Bankers Association and Rutgers University. Trust Examiner, Federal Reserve Bank of Dallas, 1933-1936, of New York, r936-r937, of Philadelphia, since r937. Author of Trust Examination (Am. Bankers' Ass'n, I938).

2 Trust examination procedure is not confined to trust investments. A more comprehensive picture of the examination as a whole has been developed by the writer of this article in thesis form for the Graduate School of Banking. This thesis is being published currently by the Trust Research Council of the American Bankers Association.

"Hovey, Trust Department Supervision and Relationships with the State Banking Department (1930) 5I Trust Companies 29-32; Barney, Examining the Trust Department (1932) 124 BANxers Mac. 139-146. ${ }^{8}$ Johnson, Review of Trust Departments by Supervisory Authority (r936) 62 Trust Companies 622.

- Jenny, The Trust Estate (1931) 9 Harv. Bus. Rev. 159; Kelix, How to Lose Your Money ProDENTIY (1933). 
action unless the instructions of the court were sought voluntarily by the trustee, the course of action challenged by one or more beneficiaries, or an' account filed. Since the imprudent fiduciary rarely sought instructions from the bench, court supervision concerned itself largely with the matter of compensating the beneficiary for losses due to the imprudent administration of the trustee. Surcharges to corporate fiduciaries, of necessity, might result in serious losses to stockholders and even to depositors of the erring bank. In an effort to avoid such losses, as well as to aid in the prevention of an increase in the volume of litigation which focused unfavorable public attention upon the banks as trustees, bank supervisors initiated a program of trust department supervision designed to improve the administration of trust accounts in all banks.

This program was developed largely by the joint efforts of the three major federal supervising agencies and the various state banking authorities. The expanded form of trust examination, made by specially trained examiners, ${ }^{5}$ was inaugurated in 1934 by the Comptroller of the Currency with respect to national banks, and in the same year by the Federal Reserve Board with respect to state bank members, the examination of the latter usually being conducted in cooperation with state bank supervising authorities. The Federal Deposit Insurance Corporation joined in the program shortly thereafter in its examinations of insured state non-member banks, which also largely are conducted in cooperation with state authorities. These examinations gave trust departments, generally, their first experience with the activities of bank examiners in the field of trust investments.

In an outline of the important features of the examination program, the following statement appears in the annual report of the Federal Reserve Board for 1934:

"In the examination of the trust department of the State member banks particular emphasis has been laid upon the policies and practices of the banks in the investment of trust funds."

The procedure of examiners in checking the policies and practices of banks in the investment of trust funds may be divided into two phases. An analysis of the investment organization and routine is made as the primary phase, and a detailed inspection of the handling of specific types of assets as an index to the investment abilities of each management supplements this analysis. As part of this survey, the investment organization is checked to ascertain that cash balances available for investment are invested promptly; ${ }^{6}$ that a competent analysis of each investment is made or secured prior to the purchase of the investment and periodically thereafter ${ }^{7}$ that informed and intelligent group judgment is exercised in the purchase, retention or sale of each trust investment; ${ }^{8}$ and that a system of review and control is utilized which assures a proper annual review of each account, together with prompt individual attention when special circumstances arise which exert a definite influence upon the intrinsic value of specific securities in various accounts.

\footnotetext{
¿Fed. Res. Bd., Annuar Report, 1934, p. 55; Fed. Deposit Ins. Corp., Annual Report, 1935, p. 23.

- Bogert, The Law of Trusts and Trustees (r935) \$6i1.

'Id. \$6r2.

${ }^{8}$ Statement of Principles of Trust Institutions, Art. IV, \$2; Fed. Res. Bd., Regulation F, Art. 5.
} 


\section{Anarysis of Organization and Routtine}

Examiners inspect the cash accounts for principal cash balances which appear to have remained uninvested for more than a reasonable time. ${ }^{9}$ This inspection is made in conjunction with an analysis of the procedure used in reporting such balances to the investment officer or division. Uninvested balances which have been carried in excess of six months are questioned unless the rule or statute in each particular jurisdiction has established a longer or shorter period of time as reasonable, in which case all balances available for investment, but not invested during such reasonable period, are investigated. ${ }^{10}$ The examiner must be satisfied that the procedure secures good results and that the investment of balances has not been neglected in any instance. If exceptions appear to exist they are called to the attention of the management with a suggestion that remedial measures be taken without delay.

The files of the investment or statistical department are inspected to ascertain that analyses of individual investments are made by the department or secured from a recognized investment analysis agency as a prerequisite to investment action, and that succeeding statements of obligor concerns are subjected to a thorough analytical review. Modern business conditions require constant attention and trust companies have discovered that it is essential to secure and retain evidence that the intrinsic value of each investment has received periodic review. The trust examiner checks this procedure in order to be satisfied that each bank is in a position to substantiate the degree of prudence which is required of it in handling investments.

The exercise of group judgment is checked by a review of the recommendations of the investment officer and the minutes of the trust committee. ${ }^{11}$ These recommendations and minutes should contain evidence to indicate that the decisions made or actions taken were based upon a full knowledge of the investment provisions of the instrument which governs the trust account involved; that the investment qualifies under these provisions; and that consideration was given to marketability, term of the security, duration of the trust, probable market conditions when the trust terminates or the investment matures, the amount of the trust, the nature of other investments in the trust, the requirements of beneficiaries and their other assets or earning capacity, and the effect of taxes upon the investment. ${ }^{12}$ In larger banks this work usually is done by a statistical force for the committee and presented to it in graphic manner on a specially designed form which is filed thereafter in the investment folder for each particular trust involved.

An annual review of all of the investments in each trust to determine whether the individual assets shall be sold or retained has become an accepted procedure in the majority of well-managed trust departments. ${ }^{13}$ Hitherto, this review has been confined to securities in the majority of institutions but is being expanded to include all trust investments in order to present a complete picture of each account. It' is surprising that more banks have not recognized the necessity of reviewing mortgages

${ }^{\circ}$ Hough v. Harvey, 71 Ill. 72 (1873); Lukens's Appeal, 47 Pa. St. 356 (1864); Estate of Whitney, 78 Cal. App. 638 (1926).

"Fed. Res. Bd., Regulation F.

${ }^{10}$ Ibid.

${ }^{23}$ Fed. Res. Bd., Regulation F.

${ }^{22}$ Restatement, TRUSTS (1935) \$227. 
and real estate with the same consideration that stocks and bonds have been receiving. The examiners have encouraged such reviews and are pointing out the advantages of presenting the complete picture to the review committee so that it may use intelligent judgment in handling each account. A form of review which is so constructed that it gives the cost and market value of each security with the rate of income received, as well as appropriate groupings to indicate unbalanced or troublesome accounts, is very desirable. The method of graphic presentation, which has been devised by a number of the large trust departments in New York City, is deserving of widespread adoption. The graphic form of review is important not only to the management but it, is very useful to the examiner in ascertaining the success of the policies of the management as they are reflected in individual accounts. Accounts with low yields, large percentages of unproductive investments, or unbalanced portfolios are selected by means of these reviews and are discussed with the management in an effort to secure special consideration with a view of remedying the undesirable condition of the account.

The final step in the examiner's analysis of the investment organization involves the system in effect for recording and controlling the amount of each individual security held. These records, commonly known as "holding cards," should contain for each security a concrol card listing the trusts holding it, together with the amounts held, as well as the gross amount held in the trust department. The routine of the department is analyzed to determine whether current reports and information which might exert adverse influences on the value of specific securities are checked in connection with these cards and the situation reported promptly to the investment committee for action. This system provides the management with an easy means of preventing concentrations of investment within a trust department and is of assistance to the examiner in determining such concentrations. If they exist, the attention of the management is directed to the dangers involved in such situations, particularly the special risks which unwieldy quantities of any security involve. Special circumstances quite often arise which require the liquidation of a specific security, and a heavy concentration makes it almost impossible to dispose of the holdings without entirely disrupting the market.

\section{Special Types of Checks to Determine the Ability of the Management}

\section{Non-Legal Investments}

After reviewing and analyzing the investment organization, the examiner checks numerous special phases of trust investment procedure which have a bearing upon the effectiveness with which the organization operates and which provide factual insight into the policies of the management relative to investments for trusts. Investments purchased during the interval between examinations are analyzed to discover any that are unauthorized or illegal. Purchases of stock or non-legal bonds are checked to the instrument or docket sheet to ascertain that each item was proper for the account involved. ${ }^{14}$ Mortgages purchased or transferred from trust to trust are

\footnotetext{
"BOGERT, op. cit., supra note $6, \$ 708$.
} 
reviewed to make certain that the status of the taxes, interest and appraisal qualified them as proper investments for trusts in which they were placed. All items which do not appear to conform are brought to the attention of the management for corrective action so that the oversights may be corrected before a loss accrues. Unless correction is obtained immediately, these items are called to the attention of the directors in the report and remedial measures are suggested or requested.

In states in which there exists a statutory distinction between investments which are legal and those which do not qualify, all non-legal securities held in accounts which require legal investments are reviewed. Unless such items are held under binding agreements with the heirs which provide unquestionable protection for the trustee in holding, the items are scheduled for special attention with the suggestion that proper agreements be obtained or sales be made with the view of avoiding future losses. A large amount of effort is expended in checking mortgages to make certain that they are legal in every respect. Numerous oversights have been discovered and corrections obtained in cases where the exceptions involved lack of appraisals, unpaid taxes or incomplete searches. These items are reported in detail to the managements involved with the recommendation that remedial action be taken wherever possible.

Purchases for trust accounts are tabulated to test the actual investment policies of the management. All investments for unrestricted accounts are separated into groups according to the type of asset either on a sample or test check basis or in entirety, depending upon the size of the trust department. The amount of investments in bonds, stocks and mortgages is tabulated as well as the amount of legal or non-legal investments. This analysis provides an accurate index of the investment attitude of the management. It seems pertinent to suggest that such a record well may be kept by each trust department for the convenience of the directors and for the purpose of serving as an effective means of control of the investment function.

Self-purchased assets are made the subject of a detailed study from examination to examination. Although this practice virtually has disappeared, various trust companies have trust accounts in which self-purchased assets were acquired by the trustee from its own banking division. ${ }^{15}$ The intrinsic value of these investments is scrutinized carefully and immediate disposition suggested where the trust account appears to be in any danger of loss. The trustee is considered as being the guarantor of such investments and a rapid diminution in the volume of such assets has been noted, due to the special effort made to dispose of them.

The acquisition or retention of investments in which conflicting interests may appear is checked carefully to see that proper attention is devoted to eliminating that conflict. Among such assets arề loans to officers, directors or employees of the institution or investments representing stocks, bonds or loans of corporations in which members of this group have a substantial interest. The attention of the management is drawn to these items at each examination with the suggestion that a special and continued effort be made to dispose of them.

\footnotetext{
${ }^{15}$ Jenney, supra note 4; BOGERT, op. cit., supra note $6, \$ 489$.
} 


\section{Stock in Trustee Institution}

The stock of the trustee institution which is held in trust accounts presents a difficult and embarrassing problem to the trustee, and it is accorded careful attention by the examiner. The best new business received by the average trust department consists of trusts or estates originating with its stockholders. Many, if not all, of these accounts contain shares of the trustee institution but few instruments incorporate specific directions for their disposition. Since it represents an investment in the trustee's own enterprise, its retention is fraught with danger, for the beneficiaries are. always in the position of claiming self-interest should the retention result in a marked loss in value. Its sale, on the other hand, is equally dangerous in many cases, for the only market for many bank stocks exists among the officers and directors or other large stockholders. If the stock is sold to any of them, the beneficiaries are also in the position of claiming self-interest should the stock later increase in value to a marked extent. Until stockholders and their attorneys can be educated to the practical necessity of incorporating specific directions in trust instruments for the retention or disposition of their holdings of stock in the trustee institution, the examiner must consider each holding carefully. Where the stock is retained without specific direction, the written authority of all beneficiaries should be secured and placed in the files as a necessary prerequisite in the absence of specific terms in the instrument. Where this authority cannot be obtained, the stock should be sold in the market, or, if this market is limited to officers and directors, the sanction of the court for a sale to them should be obtained. Such action is essential to avoid future questioning of either sale or retention of an investment which represents capital used in the trustee's own enterprise. Present examination procedure requires the scheduling of all accounts in which such stock has been acquired or retained without specific authority. The attention of the management repeatedly is called to the danger involved in such stock and suggestions are made which are designed to remove this danger.

A record of all investments purchased by the bank from trust accounts is taken by the examiner and checked to make certain that such assets were, acquired to settle claims or prevent losses to the trust for which the bank considers itself liable. ${ }^{16}$ The price paid for these investments must be adequate and the bank should not anticipate any profit from the future sale of such items. The extent of these purchases indicates to a considerable degree the success of the management in the practical handling of its investment policies.

\section{Diversification}

Diversification within each trust and within the department is studied to determine investment conditions which may exert an unfavorable influence upon either the account or the department. In jurisdictions in which statute or case law has established a legal basis for diversification, such precedent is used to measure the ability of the trust management, but in the usual jurisdiction the examiner adopts

${ }^{20}$ RestateMent, Trusts, $\$ 170$. 
the general basis that any trust in which a single investment exceeds $20 \%$ of the total fund should be checked carefully. ${ }^{17}$ Unless the concentration is permitted expressly or required by the governing instrument, the case is called to the attention of the management and appropriate suggestions are made. Each bank is encouraged to secure a balanced diversification of each account by means of investments diversified as to type, geographical location, industrial distribution and properly staggered maturities, taking into consideration the purpose of the trust, the amount of the trust estate and the financial and industrial conditions which exist at the time the investments are made. ${ }^{18}$

It should be noted that in many trust departments there frequently is a tendency, natural yet not entirely desirable, toward becoming overloaded with stock of the outstanding local enterprise. Trustors, beneficiaries and trust investment officials may be correct in their contentions that such stocks are more desirable for certain trusts than government bonds but the concentration increases the risks of losing regularity of income and possibly of principal value in case of declining industrial activity or changes in the buying habits which affect the demand for particular products. One of the types of concentrations most difficult to control is found in those cities in which a single concern has achieved noteworthy success on a national scale. In a similar manner, the securities of local concerns raise like problems in practically every city of any size in the United States. It requires real effort to avoid undesirable concentrations in stocks of outstanding enterprises, but it is the examiner's duty to remind the management of the dangers involved when a trust department becomes predominantly dependent upon a single security.

\section{Flexible Examination Program}

The examination program is flexible and designed to permit reflection of the current investment attitude of the courts as exemplified in current decisions. Examiners are encouraged to study these decisions and acquaint banks under examination with their implications. If a ruling represents a marked change or appears to indicate that a major influence will be exerted on investment policies and procedure in the trust department, the examiner suggests that the bank consult its counsel for guidance. It is difficult to draw conclusions as to the standards used in evaluating portfolios as they vary from state to state, but the conservative and generally accepted standards of trust investments are followed by examiners without exception.

The program of examination provides for the correction of exceptions during the examination if possible and the discussion of doubtful policies or procedures with the officer or committee in charge of the division and responsible for the administration in question. Doubtful policies or procedures are recorded in the written report of the examination for the attention of the directors and appropriate suggestions are made for remedial measures. After the report has been filed, matters of importance

\footnotetext{
"IT IND. Stat. (Baldwin, I934) \$7909 (10\%); WIs. StAt. (I931) \$231.32(2) (from 20 to 50\%); Dickinson, Appellant, 152 Mass. 184, 25 N. E. 99 (1889).

${ }^{13}$ Restatteanent, Trusts, \$228.
} 
usually are taken up by correspondence with the board of directors through the president.

One interesting phase of the examination is worthy of note. Numerous institutions have permitted the tax status of mortgages to become definitely unsatisfactory before taking any action to discontinue income payments in order to apply income funds from these mortgages to preserve the lien position of the trust estate. The same institutions have failed to analyze the income capacities of individual parcels of real estate received in kind or through foreclosure. The examination program has stressed the necessity of preserving the lien status on mortgages and of knowing the income results on real estate. Considerable progress has been made in controlling tax arrears. The departments in which modern systems of checking taxes have been installed are achieving satisfactory results in preventing the accumulation of large arrearages. It is now necessary to devote more attention to the income-producing propensities of individual properties as a guide in determining values and establishing sales prices. Many of these properties have been permitted to continue in the wasting or non-productive class without definite program. ${ }^{19}$

Trust examination procedure also has adopted a long range viewpoint. Although considerable improvement has been noted in the quality of assets and the earning ability of trusts in many institutions, the greatest improvement has taken place in the policies and procedure of the trust department in its handling of trust investments. Market conditions have not been propitious for immediate or wholesale exchange of investments held in accounts which are not ideally constituted at present. Such alterations must come naturally and at times when the trust corpus will not suffer a material depletion due to poor market conditions. A gradual shift in trust portfolios from unwisely-chosen investments into investments more nearly adapted to the terms and conditions of the individual account is far more desirable than sudden reformation. The program of trust examination has recognized this feature and has concentrated on the establishment of sound policies and procedure in each department. Now that these policies and procedures have received general adoption, more attention may be devoted to individual accounts in the future with stress being laid on the selection of investments adapted to each account.

Trust departments can render real assistance in this program of examination. Prompt adoption of the essential records and forms suggested in this article will provide assistance to the examiner in securing his information quickly, as well as equip the department with forms which assure good results in handling investments. .The consolidation of all data relating to the investment of funds in each individual account into an investment folder expedites and improves the handling of individual accounts. Analyses of securities, reviews, authorizations and similar items should be filed together. Cooperation in maintaining good policies and procedure constitute common ground upon which trust departments and trust examiners may work together in their efforts to achieve an improved standard of results in the investment of trust funds administered by corporate trustees.

${ }^{20}$ Id. $\$ \$ 240-242$. 